\title{
Working Capital Management a Measurement Tool for Profitability: A Study on Pharmaceutical Industry in Bangladesh
}

\author{
Md. Amir Sharif, Md. Rafiul Islam* \\ Department of Accounting \& Information Systems, Begum Rokeya University, Rangpur, Bangladesh \\ Email address: \\ sharif_brur@yahoo.com (Md. A. Sharif),rafiulais@gmail.com (Md. R. Islam) \\ *Corresponding author
}

To cite this article:

Md. Amir Sharif, Md. Rafiul Islam. Working Capital Management a Measurement Tool for Profitability: A Study on Pharmaceutical Industry in Bangladesh. Journal of Finance and Accounting. Vol. 6, No. 1, 2018, pp. 1-10. doi: 10.11648/j.jfa.20180601.11

Received: November 4, 2017; Accepted: November 20, 2017; Published: January 12, 2018

\begin{abstract}
The paper is an attempt to show the relationship between working capital and the profitability function of pharmaceutical industry in Bangladesh. Working capital management as a financial strategy has its effects on liquidity as well as profitability of the firm. To serve the study mostly secondary data have been used of pharmaceutical companies listed in DSE \& CSE and data include time series from annual reports of the selected companies. Sample size includes10 selected pharmaceutical companies and their five years annual data. Multiple regression and correlation have been used to analyze the data. To serve the study perspective, this paper considered the working capital indicators such as (Account Receivable Turnover in days, Account payable Turnover in days, Inventory Turnover in days and Cash conversion cycle) as independent variable where as Profitability indicator (Return on Assets) as dependent variable and found there is a significant relationship between the variables studied. Finally the study shows the rejection of Null hypotheses $\left(\mathrm{H}_{0}\right)$ which mentions that there is significant effect of working capital on firm's profitability. The inference drawn from the study would be able to provide the basis for rethinking the practices of working capital management for competitive survival.
\end{abstract}

Keywords: Working Capital Management, Profitability, DSE, CSE, Conversion Cycle, Hypotheses

\section{Introduction}

Pharmaceutical industry is one of the important industries to country development in the light of the main important basis for construction industry and also the important indicator showing domestic economic growth. Working capital is termed as the life blood circulation for organization. Working capital provides the current status of an organization as well as capability to continue operation. Working capital management, which deals with management of current assets and current liabilities, directly affect profitability and market valuation of firms [24]. Working Capital mainly represents the current assets of a firm which is the portion of financial resources of business that change from one type to another during the day-to-day execution of business [3]. Current assets mainly comprise of cash, prepaid expenses, short-term investments, accounts receivable and inventory.
Net working capital can be measured by deducting current liabilities of a firm from its current assets. If the value of current assets is less than that of current liabilities, net working capital would have a negative value showing a deficit working capital.

To know about the income generation capacity of a company, gross profit ratio is not sufficient. A major part of fund is also used for to operate day to day business. If working capital is not managed properly, company can reach to crucial financial situation.

In Bangladesh the pharmaceutical sector is one of the most developed hi-tech sectors within the country's economy. After the declaration of Drug Control Ordinance - 1982, the development of this sector was accelerated. The professional knowledge, thoughts and innovative ideas of the pharmaceutical professionals are the key factors for these developments. Due to recent development of this sector, it is exporting medicines to global market including European 
market. This sector is also providing $97 \%$ of the total medicine requirement of the local market. Leading pharmaceutical companies are expanding their business with the aim to expand export market. Recently few new industries have been established with high tech-equipment and professionals which will enhance the strength of this sector.

Further, working capital has to play a vital role to keep pace with the scientific and technological developments that are taking place in the concerned area of pharmaceutical industry. If new ideas, methods and techniques are not injected or brought into practice for want of working capital, the concern will certainly not be able to face competition and survive. In this context, working capital management has a special relevance and a thorough investigation regarding working capital practice in the pharmaceutical industry is of utmost importance.

\section{Objectives}

(a). General objective

The broader objective of the study is to identify the impact of working capital management on organizational profitability and their relationship therein.

(b). Specific objectives:

i. To assess the nature and extent of relationship between working capital management and profitability;

ii. To assess the impact of working capital management on profitability;

iii. To suggest some recommendations based on analyses;

\section{Review of Related Literature}

It is presumed that no working capital, no operation. The findings revealed that the average collection period and the average payment period are negative and statistically significant for profitability, implying that firms which efficiently manage their accounts receivable and those that pay their creditors on time perform better than those that do not. Additionally, a positive statistically significant relationship between the number of days in inventory and profitability was supported suggesting that firms which stock-up and maintain their inventory levels suffer less from stock-outs and avoid challenges of securing financing when needed [7].

Working capital is the dependent variable while firm size, profitability, leverage, operating cycle, growth and level of economic activity are independent variable. The result of multiple regression show highly significant results. Working capital is negatively linked with firm size while positively linked with growth and level of economic activity for UK Pharmaceutical firms. Furthermore, insignificant results of working capital with operating cycle, profitability and leverage are observed [20]. A study on Nigerian Manufacturing Companies found a significant negative relationship between the components of working capital (DCP, APP and ITID) and profitability (ROI). The study therefore concluded that working capital management has significant impact on profitability of manufacturing companies and recommended that companies should manage their cash, accounts receivables, inventories and accounts payable with a view to reducing the cash conversion cycle so as to increase their profitability amongst other things [10]. The correlation and spearman's ranking method indicates weak correlation and negative relationship between liquidity and profitability [14].

An early study examined the relationship between firm working capital policies and business cycle [13]. More recent studies have investigated the degree to which firms' reliance on bank borrowing to finance working capital is cyclical [4], and the influence of business indicators on the determinants of working capital management [2]. These studies have independently linked working capital to corporate profitability and the business cycle. A study found i) a negative relationship between profitability (measured through gross operating profit) and average days of accounts receivable and ii) a positive relationship between cash conversion cycle and profitability [6]. Prior study discovered that significant level of relationship between the profitability indices and various liquidity indices as well as working capital components and recommended that the firms should forecast their sales and hold cash enough as according to their projected sales level, so that they be able to take advantage of the bargaining position while making purchases and thus reduce cost [19]. Previous study on management of working capital and its effect on profitability of manufacturing companies listed on Nairobi securities exchange (NSE), Kenya. In their study they revealed that gross operating profit was positively correlated with average collection period and average payment period but negatively correlated with cash conversion cycle [17]. Profitability is a measure of the amount by which a firm's revenues exceeds its relevant expenses. It is the potential of making profits that encourage entrepreneurs to take risks to invest in a 144 business, so the first role of profits is to reward owners for risks taken when investing in a business. A low profit margin would suggest ineffective management and investors would be hesitant to invest in the company [16]. A researcher found in his research that a firm is required to maintain a balance between liquidity and profitability while conducting its day to day operations. The manager of a business entity is in a dilemma of achieving desired trade-off between liquidity and profitability in order to maximize the value of a firm [18]. Some researchers investigated relationship between working capital management and corporate profitability of listed companies in the Athens Stock Exchange. The results of the article showed that there was a statistically significant relationship between profitability and cash conversion cycle [11]. By using cash conversion cycle as a liquidity indicator in Greek food industry, a study found significant positive relationship between cash conversion cycle and the traditional liquidity measures of current and quick ratios. 
Concurrently negative relationship between the current and quick ratios and debt to equity ratio and positive relationship with the times interest earned ratio [12].

Working capital management is a very important component of corporate finance because it directly affects companies' liquidity and profitability [3, 5, 21]. Therefore, efficient management of working capital is a fundamental part of the overall corporate strategy to create shareholder value. In general, companies try to keep an optimal level of working capital that maximizes their value $[1,3]$.

A prior study found that WCM has strong impact on the profitability and risk factor of the firms which in turn enhance the value of the firms. Research has confirmed empirically by studying the relationship or association of WCM and profitability that aggressive working capital management policies maximize the profitability ratio [23]. Particularly, the work of Jose et al. [8] in this regard provides substantial manifestation regarding the financial advantages of aggressive working capital management from USA companies. Cash Conversion cycle (CCC) means the days in numbers in which a firm get or convert back its economic recourses into cash. According to a study, it is possible to say that CCC is the most popular measure of WCM [22]. Taking the case of Malaysian firms [25] found significant association between profitability and CCC during the period 1996 to 2006.

Despite the huge amount of literature on working capital management and profitability, there is a gap of studies with focused objectives to this sector in Bangladesh considering the straight link on the impact of increase or decrease in working capital management efficacy on firms' profitability.

\section{Research Design and Methodology}

Methodology

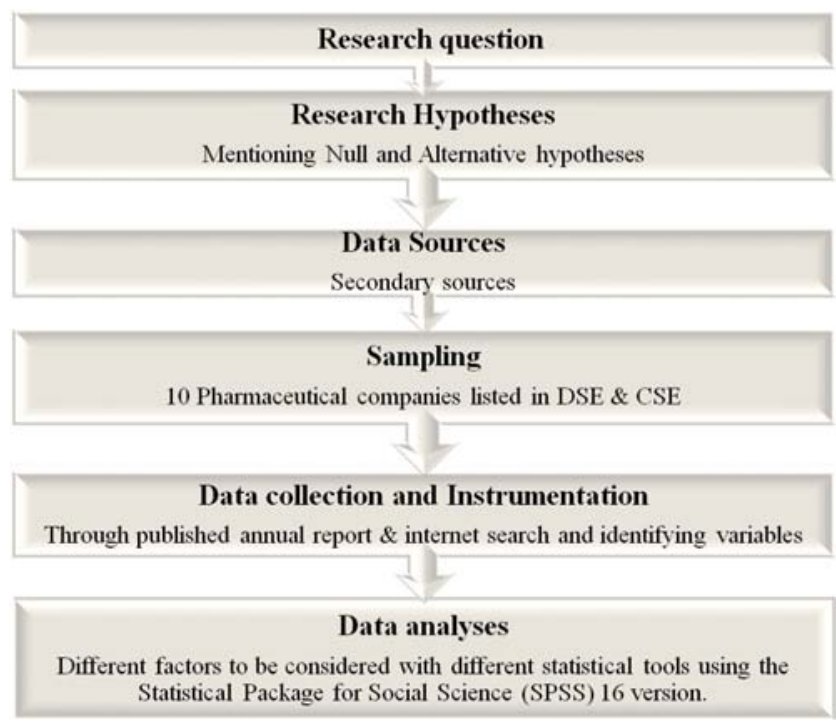

Figure 1. Methodology.

Since the main objective of this study is determine the nature and extent of the relationship between working capital management and profitability as well as to explore the joint impact of different components of working capital management on profitability, therefore the nature of the study is descriptive. Based on the research approach deductive approach has been chosen for this study. The study is both qualitative and quantitative in nature.

Research Question

Is there truly worthy any effect of working capital (AR days, AP days, INV days, and CCC) on Profitability (ROA)?

Research Hypotheses

The study makes a set of testable hypothesis the Null Hypotheses $\left(\mathrm{H}_{0}\right)$ versus the Alternative ones $\left.\left(\mathrm{H}_{1}\right)\right\}$ to examine the relationship between working capital management and profitability.

$\mathrm{H}_{0} 1$ : There is no significant effect of Number of days Account receivable on the profitability of Pharmaceutical industry.

$\mathrm{H}_{1} 1$ : There is significant effect of Number of days Account receivable on the profitability of Pharmaceutical industry

$\mathrm{H}_{0} 2$ : There is no significant effect of Number of days Account payable on the profitability of Pharmaceutical industry.

$\mathrm{H}_{1}$ 2: There is significant effect of Number of days Account payable on the profitability of Pharmaceutical industry.

$\mathrm{H}_{0}$ 3: There is no significant effect of Number of days Inventory on the profitability of Pharmaceutical industry.

$\mathrm{H}_{1} 3$ : There is significant effect of Number of days Inventory on the profitability of Pharmaceutical industry.

$\mathrm{H}_{0} 4$ : There is no significant effect of $\mathrm{CCC}$ on the profitability of Pharmaceutical industry.

$\mathrm{H}_{1} 4$ : There is significant effect of CCC on the profitability of Pharmaceutical industry.

To meet the objectives different hypotheses will be experimented considering the mentioned dependent and independent variable. Pearson product moment correlation coefficient ( $r$ ) has been used to determine the direction of the linear relationship and t test at 5\% level of significance with one-tailed critical value to test the hypotheses.

Data source

Mostly the secondary sources of information have been used to conduct the study. The required sources include annual report, business magazines, different related journals, books etc. The data for this study would be taken to meet the objectives of the study. The time series data have been collected for some selected pharmaceuticals company listed in DSE \& CSE in Bangladesh on the basis of availability of data. Information would be sought on different working capital and profitability variables from operational performance for those periods.

Population and Sample

Assuming the Pharmaceutical Industry of Bangladesh as Population, Square Pharmaceutical Limited, Renata Limited, Beximco Pharmaceutical Limited, Ibn sina Pharmaceutical Limited, Healthcare, Eskayef, Aristopharma, A. C. I, Acme, Opsonin Pharma (10 pharmaceutical companies) have been 
selected as sample from this industry considering ranking (market position) and availability of published data.

Data Collection and Instrumentation

The study used only secondary time series data that were collected from the published annual reports of the following selected pharmaceutical companies. The sample companies were selected on the basis of availability of at least Five years (2010-2014) published annual reports to the public. Five (05) years data have been studied for easy understanding, presentation as well as analyses with perfection. Regression analysis has been used to investigate the impact of Working Capital Management on corporate profitability. The various parameters used for the study are:

Dependent Variable:

ROA (Return on Total Assets) =Annual Net Income/Average Total Assets

Independent Variables:

AR Days (Number of Days Accounts Receivable) $=365 \mathrm{x}$ [accounts receivable/sales].

INV Days (Number of Days Inventory) $=365 \mathrm{x}$ (inventories/purchases).

AP Days (Number of Days Accounts Payable) $=365 \mathrm{x}$ [accounts payable/purchases]

CCC (Cash Conversion Cycle) $=$ (Number of days Account receivable + Number of days Inventory - Number of days Account payable).

Control Variable:

Size (Size of the firm i.e. logarithm of assets)

GR Sales (Growth in Sales i.e. (Sales1-Sales0)/ Sales 0)

Lev (Financial Debt or leverage Ratio i.e. Debt / Total assets)

CR (Current Assets to Current Liabilities)

Conceptual framework

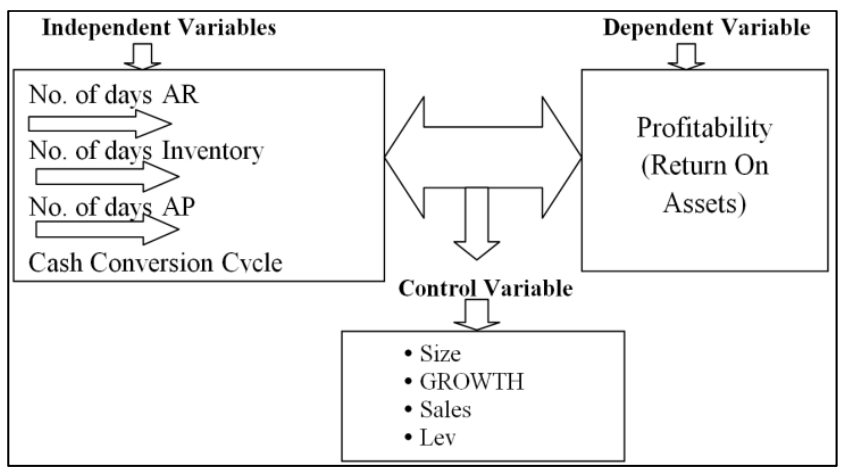

Figure 2. Conceptual framework.

Statistical Model:

The following regression equations have been developed:
Regression equation 1

ROA it $=\beta_{0}+\beta_{1}$ AR Days it $+\beta_{2}$ SIZE it $+\beta_{3}$ GROWTH it $+\beta_{4}$ LEV it $+\beta_{5}$ CR it $+\mathrm{e}$

Regression Equation 2

ROA it $=\beta_{0}+\beta_{1}$ INV Days it $+\beta_{2}$ SIZE it $+\beta_{3}$ GROWTH it

$+\beta_{4}$ LEV it $+\beta_{5}$ CR it $+\mathrm{e}$

Regression Equation 3

ROA it $=\beta_{0}+\beta_{1}$ AP Days it $+\beta_{2}$ SIZE $f$ it $+\beta_{3}$ GROWTH

it $+\beta_{4}$ LEV it $+\beta_{5}$ CR it $+\mathrm{e}$

Regression Equation 4

ROA it $=\beta_{0}+\beta_{1}$ CCC it $+\beta_{2}$ SIZE $f$ it $+\beta_{3}$ GROWTH it +

$\beta_{4} \mathrm{LEV}$ it $+\beta_{5} \mathrm{CR}$ it $+\mathrm{e}$

Where,

$\beta_{0}=$ Constant

$\beta_{1}, \beta_{2}, \beta_{3}, \beta_{4}, \beta_{5}=$ Respective coefficient

AR Days, INV Days, AP Days, $\mathrm{CCC}=$ Independent variable

SIZE, GROWTH, LEV, CR= Control variable

$\mathrm{e}=$ Error term

Among many variables AR Days, INV Days, AP Days, CCC have been termed as independent variable due to finding out the impact of those variables on profitability considering regression result, coefficients result and testing hypotheses.

\section{Analyses \& Findings}

It is found that there is a negative correlation of ROA and the number of, days of inventory, days of accounts payable, the cash conversion cycle as well as leverage and current ratio while positive correlation with the number of days of accounts receivable, and GROWTH and SIZE. With regard to correlations between the independent or control variables, maximum values are found only between the INV and CCC (0.801) and the number of days of Accounts payable (AP) and the number of days of Accounts receivables (0.380). Since there is one high value of correlation coefficient among the variables used in the study, there is high chance of potential multicollinearity problem. Assuming moderate or insignificant effect of multicollinearity thus effect has been ignored here. Multicollinearity generally occurs when there are high correlations between two or more independent variables. In other words, one independent variable can be used to predict the other. This creates redundant information, skewing the results in a regression model. It is therefore a type of disturbance in the data, and if present in the data the statistical inferences made about the data may not be reliable.

Table 1. Correlation matrix.

\begin{tabular}{llllllll}
\hline & ROA & AR & INV & AP & CCC & SIZE & Growth \\
\hline ROA & 1 & & & & & \\
AR & $.163^{*}$ & 1 & & & & \\
INV & -.196 & .077 & 1 & & & \\
AP & -.133 & .380 & .189 & 1 & & \\
CCC & -.145 & .293 & $.801^{*}$ & -.311 & 1 & \\
SIZE & .027 & -.059 & -.160 & -.359 & .089 & 1 \\
\hline
\end{tabular}




\begin{tabular}{|c|c|c|c|c|c|c|c|c|c|}
\hline & ROA & $\mathbf{A R}$ & INV & $\mathbf{A P}$ & $\mathrm{CCC}$ & SIZE & Growth & Lev & CR \\
\hline GROWTH & .132 & .339 & .290 & .392 & .164 & .144 & 1 & & \\
\hline LEV & $-.601 *$ & $-.812^{*}$ & .245 & -.208 & -.088 & -.051 & -.297 & 1 & \\
\hline $\mathrm{CR}$ & $-.526^{*}$ & -.324 & .082 & -.163 & .036 & .266 & .251 & .202 & 1 \\
\hline
\end{tabular}

Period: $2010-14$.

Source: SPSS output.

Notes: *Significant at 95 per cent level of significance.

Pearson's correlation analysis is also used for data to see the relationship between variables such as those between working capital management and profitability. If efficient working capital management increases profitability, one should expect a negative relationship between the measures of working capital management and profitability variable. There is a negative relationship between return on asset profitability on the one hand and the measures of working capital management on the other hand. This is consistent with the view that the time lag between expenditure for purchases of raw material and the collection of sales of finished goods can be too long and that decreasing this time lag increases profitability.

Correlation Matrix shows that the dependent variable (ROA) is negatively correlated with the independent variable (INV \& CCC) where as positively correlated with (AR \& AP). These refer to the same directed movement between
ROA and AR, AP where as reverse movement between ROA and INV and CCC.

Regression Models 1: Firm Profitability and Number of Days Accounts Receivables

Table 2. Model Summary considering AR.

\begin{tabular}{lllll}
\hline Model & R & R Square & Adjusted R Square & $\begin{array}{l}\text { Std. Error of } \\
\text { the Estimate }\end{array}$ \\
\hline 1 & .904 & .817 & .0 .735 & 9.855 \\
\hline
\end{tabular}

a. Predictors: (Constant), AR, SIZE, Growth, CR, Lev.

b. Dependent Variable: ROA.

Period: 2010-14.

The adjusted R-square value of the model is $73.5 \%$, which obviously shows that $73.5 \%$ variation of the dependent variable (ROA) is due to the independent variables, so this indicates the strong explanatory power of regression there in.

Table 3. ANOVA considering AR.

\begin{tabular}{lllllll}
\hline Model & & Sum of Squares & df & Mean Square & F & F-Sig. (Tab.) \\
\hline 1 & Regression & 298.212 & 4 & 74.553 & 5.60 \\
& Residual & 66.565 & 5 & 13.313 & \\
& Total & 364.777 & 9 & & \\
\hline
\end{tabular}

a. Predictors: (Constant), AR, SIZE, Growth, CR, Lev.

b. Dependent Variable: ROA.

Period: 2010-14.

From the table 3 above the value of F-stat is found to be 5.60 and is significant as the level of significance is less than $5 \%$ where tabulated value is 5.19. Results show that Account receivables in days, Current ratio, Leverage, Size of the firm and Growth of the firm have impact on return on assets (ROA) of Bangladeshi pharmaceuticals industries.

Table 4. Coefficients considering AR

\begin{tabular}{|c|c|c|c|c|c|c|}
\hline \multirow{2}{*}{ Model } & \multicolumn{2}{|c|}{ Unstandardized Coefficients } & \multirow{2}{*}{$\begin{array}{l}\text { Standardized Coefficients } \\
\text { Beta }\end{array}$} & \multirow{2}{*}{$\mathbf{t}$} & \multirow{2}{*}{ t-Sig. (Tab.) } & \multirow{2}{*}{ Sig. } \\
\hline & B & Std. Error & & & & \\
\hline (Constant) & 3.221 & 3.021 & & .637 & \multirow{6}{*}{2.262} & .499 \\
\hline Growth & -.184 & .223 & -.077 & -.569 & & .602 \\
\hline Lev & -1.315 & .385 & -.480 & -4.102 & & .004 \\
\hline $\mathrm{CR}$ & -.584 & .264 & -.299 & -2.154 & & .057 \\
\hline SIZE & .402 & .390 & .180 & .956 & & .408 \\
\hline AR & .007 & .009 & .301 & 2.703 & & .008 \\
\hline
\end{tabular}

a. Dependent Variable: ROA.

Period: 2010-14.

Thus, the ROA is predicted with about $81.7 \%$ explanatory power by the following model:

$\mathrm{ROA}=3.221+.007 \mathrm{AR}+0.402 \mathrm{SIZE}-0.184 \mathrm{GROWTH}-$

$1.315 \mathrm{LEV}-0.584 \mathrm{CR}+\mathrm{e}$

Whenever evaluating the significance of each independent variable on the dependent variable ROA, result being showed that all the independent variables affect the dependent variable whether positively or negatively. Account receivables in days have a significant effect on ROA as the calculated $\mathrm{t}$ value is higher than tabulated value at $5 \%$ level of significance. In corporate finance theory, lesser the number of days of accounts receivables, more it will add to the profitability of the company. But following at the coefficient value of number of days of accounts receivables (AR) by Bangladeshi Pharmaceutical companies shows that an increase in the number of days of accounts receivables by one day is associated with an increase in return on assets (ROA) by 0.7 per cent. The result found here renounces the 
theory of resourceful management of working capital. The coefficient value of $\mathrm{AR}$ is $0.8 \%$ which is much lower than significance level at $5 \%$, thus indicates the significant impact on profitability. The findings of this study drastically vary from those conducted by Deloof [3], Lazaridis and Tryfonidis [11], Raheman and Nasr [21]. This reveals that in Bangladeshi Pharmaceutical companies, managers can improve profitability by increasing the credit period granted to their customers. Under this study's findings the lower current ratio of the company will add to its profitability. This is consistent with theory that lesser the money blocked in current assets more will be profitability of the firm.

Regression Models 2: Firm Profitability and Number of Days Accounts Payables
Table 5. Model Summary considering AP.

\begin{tabular}{lllll}
\hline Model & R & R Square & Adjusted R Square & $\begin{array}{l}\text { Std. Error of } \\
\text { the Estimate }\end{array}$ \\
\hline 1 & $.901^{\mathrm{a}}$ & .812 & .0 .731 & 7.4116 \\
\hline
\end{tabular}

a. Predictors: (Constant), AP, CR, Lev, SIZE, Growth.

b. Dependent Variable: ROA.

Period: 2010-14.

The adjusted R-square value of the model is $73.1 \%$, which obviously shows that $73.1 \%$ variation of the dependent variable (ROA) is due to the independent variables, so this indicates the strong explanatory power of regression there in.

Table 6. ANOVA considering AP.

\begin{tabular}{|c|c|c|c|c|c|c|}
\hline Model & & Sum of Squares & df & Mean Square & $\mathbf{F}$ & F-Sig. (Tab.) \\
\hline \multirow[t]{3}{*}{1} & Regression & 296.127 & 4 & 74.032 & 5.391 & 5.19 \\
\hline & Residual & 68.65 & 5 & 13.732 & & \\
\hline & Total & 364.777 & 9 & & & \\
\hline
\end{tabular}

a. Predictors: (Constant), AP, CR, Lev, SIZE, Growth.

b. Dependent Variable: ROA.

Period: 2010-14.

From the table 6 above the value of F-stat is found to be 5.391 and is significant as the level of significance is less than $5 \%$ which is 5.19. Results show that Account Payable in days, Current ratio, Leverage, Size of the firm and Growth of the firm have impact on return on assets (ROA) of Bangladeshi pharmaceuticals industries.

Table 7. Coefficients considering AP.

\begin{tabular}{|c|c|c|c|c|c|c|}
\hline \multirow{2}{*}{ Model } & \multicolumn{2}{|c|}{ Unstandardized Coefficients } & \multirow{2}{*}{$\begin{array}{l}\text { Standardized Coefficients } \\
\text { Beta }\end{array}$} & \multirow{2}{*}{$\mathbf{t}$} & \multirow{2}{*}{ t-Sig. (Tab.) } & \multirow{2}{*}{ Sig. } \\
\hline & B & Std. Error & & & & \\
\hline (Constant) & 4.108 & 5.012 & & .598 & \multirow{5}{*}{2.262} & .897 \\
\hline Growth & -.209 & .426 & -.098 & -.444 & & .598 \\
\hline Lev & -1.289 & .259 & -.648 & -6.021 & & .005 \\
\hline CR & -.748 & .167 & -.402 & -1.568 & & .015 \\
\hline SIZE & .415 & .345 & .200 & .888 & & .456 \\
\hline
\end{tabular}

a. Dependent Variable: ROA.

Period: 2010-14.

Thus, the ROA is predicted with about $81.2 \%$ explanatory power by the following model:

$\mathrm{ROA}=4.108-.111 \mathrm{AP}+0.415 \mathrm{SIZE}-0.209 \mathrm{GROWTH}-$ 1.289 LEV - $0.748 \mathrm{CR}+\mathrm{e}$

Table 7 shows that there is negative relationship between days accounts payables and profitability as increase in one unit of days accounts payables results in .111 units of decrease in profitability. The coefficient value of AP is $3.4 \%$ which is much lower than significance level at 5\%, thus indicates the significant impact on profitability. This supports the results of Deloof [3] and Raheman \& Nazr [21] the results of the information technology sector reveal that more profitable firms wait longer to pay their bills. The number of days a firm takes to pay its suppliers (creditors) depends upon its profitability. More profitable firms pay their creditors early as compared to less profitable ones, which in turn affect the profitability of the firm. The regression results show a negative relationship between number of days of accounts payables (AP) and firm profitability as measured by return on assets. The results of other variables except of size of firm as measured by natural logarithm of assets also show the negative relationship with profitability.

Regression Models 3: Firm Profitability and Number of Days Inventory

Table 8. Model Summary considering INV.

\begin{tabular}{lllll}
\hline Model & R & R Square & Adjusted R Square & $\begin{array}{l}\text { Std. Error of } \\
\text { the Estimate }\end{array}$ \\
\hline 1 & $.905^{\text {a }}$ & .820 & .738 & 5.4023 \\
\hline
\end{tabular}

a. Predictors: (Constant), INV, CR, Lev, SIZE, Growth.

b. Dependent Variable: ROA.

Period: 2010-14.

The adjusted R-square value of the table 9 is $73.8 \%$, which obviously shows that $73.8 \%$ variation of the dependent variable (ROA) is due to the independent variables, so this 
indicates the strong explanatory power of regression there in.

Table 9. ANOVA considering INV.

\begin{tabular}{lllllll}
\hline Model & & Sum of Squares & df & Mean Square & F & F-Sig. (Tab.) \\
\hline 1 & Regression & 299.062 & 4 & 74.766 & 5.689 & 5.19 \\
& Residual & 65.715 & 5 & 13.143 & \\
& Total & 364.777 & 9 & & & \\
\hline
\end{tabular}

a. Predictors: (Constant), INV, CR, Lev, SIZE, Growth.

b. Dependent Variable: ROA.

Period: 2010-14.

From the table 9 above the value of F-stat is found to be 5.689 and is significant as the level of significance is less than $5 \%$ with tabulated value of 5.19. Results show that Inventory turnover in days, Current ratio, Leverage, Size of the firm and Growth of the firm have impact on return on assets (ROA) of Bangladeshi pharmaceuticals industries.

Table 10. Coefficients considering INV.

\begin{tabular}{lllllll}
\hline \multirow{2}{*}{ Model } & \multicolumn{2}{l}{ Unstandardized Coefficients } & Standardized Coefficients & \multirow{2}{*}{ t } & \multirow{2}{*}{ t-Sig. (Tab.) } & Sig. \\
\cline { 2 - 4 } & $\mathbf{B}$ & Std. Error & Beta & .648 & .333 \\
(Constant) & 2.987 & 4.124 & & -.056 & -5.215 & .458 \\
Growth & -.211 & .268 & -.948 & -3.102 & 2.262 & .001 \\
Lev & -2.012 & .421 & -.458 & .790 & .016 \\
CR & -.549 & .168 & .097 & 2.454 & .302 \\
SIZE & .487 & .397 & .056 & & .010 \\
INV & -.031 & .002 & &
\end{tabular}

a. Dependent Variable: ROA.

Period: $2010-14$.

Thus, the ROA is predicted with about $82.0 \%$ explanatory power by the following model:

$\mathrm{ROA}=2.987-.031 \mathrm{INV}+0.487 \mathrm{SIZE}-0.211 \mathrm{GROWTH}-$ 2.012 LEV - $0.549 \mathrm{CR}+\mathrm{e}$

Table 10 shows the results of regression equation 3 which shows that there is a negative relationship between inventory days and profitability. Increase in one unit of inventory days increases the profitability of the organization by -.031 units. The analysis suggests that managers can increase the profitability of the organizations by reducing the number of days inventory is held in the organization. This shows quick movement of inventory in the firms and saving the firm from obsolescence cost and losses due to pilferage of inventory. The coefficient value of INV is $1 \%$ which is much lower than significance level at $5 \%$, thus indicates the significant impact on profitability. As per corporate finance theory, lesser the number of days of inventory holding, higher will be profitability of the company. The results are however not consistent with some of the earlier studies by Lazaridis \& Tryfondis [11] Padachi [18]. The other variables of the equation a positive relationship between profitability and size of firm, growth of sales, current assets to total assets and current assets turnover ratio and a negative relationship between profitability \& size of sales as measured by natural logarithm of sales, debt, current liabilities to total liabilities ratio.

Regression Models 4: Firm Profitability and Cash Conversion Cycle

Table 11. Model Summary considering CCC.

\begin{tabular}{lllll}
\hline Model & R & R Square & Adjusted R Square & $\begin{array}{l}\text { Std. Error of } \\
\text { the Estimate }\end{array}$ \\
\hline 1 & $.903^{\mathrm{a}}$ & .816 & .734 & 5.3841 \\
\hline
\end{tabular}

a. Predictors: (Constant), CCC, CR, Lev, SIZE, Growth.

b. Dependent Variable: ROA.

Period: 2010-14.

The adjusted R-square value of the model is $73.4 \%$, which obviously shows that $73.4 \%$ variation of the dependent variable (ROA) is due to the independent variables, so this indicates the strong explanatory power of regression there in.

Table 12. ANOVA considering CCC.

\begin{tabular}{llllll}
\hline Model & & Sum of Squares & df & Mean Square & F \\
\hline 1 & Regression & 297.722 & 4 & 74.431 & 5.550 \\
& Residual & 67.055 & 5 & 13.411 & \\
& Total & 364.777 & 9 & & \\
& & & & \\
\hline
\end{tabular}

a. Predictors: (Constant), CCC, CR, Lev, SIZE, Growth.

b. Dependent: ROA.

Period: 2010-14.

From the table 12 above the value of F-stat is found to be 5.550 and is significant as the level of significance is less than $5 \%$ with tabulated value of 5.19. Results show that cash conversion cycle in days, Current ratio, Leverage, Size of the firm and 
Growth of the firm have impact on return on assets (ROA) of Bangladeshi pharmaceuticals industries.

Table 13. Coefficients considering CCC.

\begin{tabular}{|c|c|c|c|c|c|c|}
\hline \multirow{2}{*}{ Model } & \multicolumn{2}{|c|}{ Unstandardized Coefficients } & \multirow{2}{*}{$\begin{array}{l}\text { Standardized Coefficients } \\
\text { Beta }\end{array}$} & \multirow{2}{*}{ t } & \multirow{2}{*}{ t-Sig. (Tab.) } & \multirow{2}{*}{ Sig. } \\
\hline & B & Std. Error & & & & \\
\hline (Constant) & 2.697 & 4.031 & & .897 & \multirow{6}{*}{2.262} & .421 \\
\hline Growth & -.201 & .312 & -.056 & -.505 & & .568 \\
\hline Lev & -2.311 & .303 & -.856 & -6.021 & & .001 \\
\hline $\mathrm{CR}$ & -.597 & .268 & -.312 & -1.968 & & .021 \\
\hline SIZE & .265 & .400 & .069 & .568 & & .612 \\
\hline $\mathrm{CCC}$ & -.065 & .004 & .077 & 2.662 & & .048 \\
\hline
\end{tabular}

a. Dependent Variable: ROA.

Period: 2010-14.

Thus, the ROA is predicted with about $81.6 \%$ explanatory power by the following model:

ROA $=2.697-.065 \mathrm{CCC}+0.265$ SIZE -0.201 GROWTH 2.311 LEV - $0.597 \mathrm{CR}+\mathrm{e}$

Table 13 shows that there is a negative relationship between cash conversion cycle and profitability with coefficient -0.065 . This refers that if the firm is able to decrease its cash conversion cycle, it can increase its profitability. By analyzing the results it has been concluded that if the firm is able to reduce these time periods, then the firm is efficient in managing working capital. This efficiency will lead to increasing its profitability. The coefficient value of CCC is $4.8 \%$ which is much lower than significance level at $5 \%$, thus indicates the significant impact on profitability. The results are consistent with earlier studies like those done by Lazaridis and Tryfonidis [11] and Raheman and Nasr [21] which indicate an inverse relation between CCC with profitability of firms. The results of other variables of the equation a positive relationship between profitability and size of firm as measured by natural logarithm of assets, growth of sales, current assets to total assets ratio, current assets turnover ratio and a negative relationship between size of sales as represented by logarithm of sales, debt and current liabilities to total liabilities ratio.

Research question analysis

Yes. The coefficient value of number of days of accounts receivables (AR), days accounts payables (AP), inventory days (INV), cash conversion cycle (CCC) shown by Bangladeshi Pharmaceutical companies implies that there are impact on profitability (ROA) whether positive or negative. It is found that days of accounts receivables (AR) is with positive impact and the others are with negative impact.

Hypotheses tests (Model)

1. $\mathrm{H} 1=$ The value of F-stat is found to be 5.60 and is significant as the level of significance is less than $5 \%$ where the tabulated value is 5.19 . Hence it was found that Account receivables in days have significant impact on return on assets of Bangladeshi pharmaceuticals industries. Hence rejecting null $\left(\mathrm{H}_{0} 1\right)$ hypothesis and accepting alternative $\left(\mathrm{H}_{1} 1\right)$ hypothesis.

2. $\mathrm{H} 2=$ The value of F-stat is found to be 5.391 and is significant as the level of significance is less than $5 \%$. Hence it was found that Account Payable in days has impact on return on assets (ROA) of Bangladeshi pharmaceuticals industries. Hence rejecting null $\left(\mathrm{H}_{0} 2\right)$ hypothesis and accepting alternative $\left(\mathrm{H}_{1} 2\right)$ hypothesis.

3. $\mathrm{H} 3=$ The value of F-stat is found to be 5.689 and is significant as the level of significance is less than $5 \%$. Hence it was found that Inventory turnover in days have impact on return on assets of Bangladeshi pharmaceuticals industries. Hence rejecting null $\left(\mathrm{H}_{0} 3\right)$ hypothesis and accepting alternative $\left(\mathrm{H}_{1} 3\right)$ hypothesis.

4. $\mathrm{H} 4=$ The value of F-stat is found to be 5.550 and is insignificant as the level of significance is less than $5 \%$. Hence it was found that cash conversion cycle in days have impact on return on assets (ROA) of Bangladeshi pharmaceuticals industries. Hence rejecting null $\left(\mathrm{H}_{0} 4\right)$ hypothesis and accepting alternative $\left(\mathrm{H}_{1} 4\right)$ hypothesis.

Hypotheses tests (Independent variable)

1. AR: The calculated t-value is 2.703 which is higher than the critical value under one tailed $5 \%$ significant level under df 9. So Null hypothesis $\left(\mathrm{H}_{0} 1\right)$ is rejected and alternative hypothesis $\left(\mathrm{H}_{1} 1\right)$ is accepted.

2. AP: The calculated t-value is 3.298 which is higher than the critical value under one tailed $5 \%$ significant level under df 9. So Null hypothesis $\left(\mathrm{H}_{0} 2\right)$ is rejected and alternative hypothesis $\left(\mathrm{H}_{1} 2\right)$ is accepted.

3. INV: The calculated t-value is 2.454 which is higher than the critical value under one tailed $5 \%$ significant level under df 9. So Null hypothesis $\left(\mathrm{H}_{0} 3\right)$ is rejected and alternative hypothesis $\left(\mathrm{H}_{1} 3\right)$ is accepted.

4. CCC: The calculated t-value is 2.662 which is higher than the critical value under one tailed $5 \%$ significant level under df 9 . So Null hypothesis $\left(\mathrm{H}_{0} 4\right)$ is rejected and alternative hypothesis $\left(\mathrm{H}_{1} 4\right)$ is accepted.

\section{Recommendations}

However, with the view of the ultimate remarks, the following suggestions are given for increasing efficiency in working capital management as well as profitability on the basis of the analysis:

a. Inventory should be turned out quickly since there is a negative relationship between INV and ROA.

b. Effective Cost audit should be ensured constantly.

c. Should ensure proper inventory management system.

d. Baumol Model, Miller-Orr, etc. Model should be used for better management of cash, cash budgeting, 
statement of cash flow, statement of fund flow for cost minimization.

e. Should try to reduce lead time.

f. Account Receivable turnover in days should be reduced.

g. Inventory turnover in days should be reduced.

h. Investment in Current Assets should be increased.

i. Organized liquidity management system should be implemented.

j. Standard working capital level should be determined.

\section{Conclusions}

Working capital management is important part in firm financial management decision. When working capital is not managed and allocated properly, it refers management inefficiency and reduces the benefits of short term investments. On the other hand, if working capital is too low, the company may miss a lot of profitable investment opportunities or suffer short term liquidity crisis, leading to degradation of company credit, as it cannot respond effectively to temporary capital requirements. The present study investigates the relationship between the working capital management and profitability of 10 Bangladeshi Pharmaceutical companies for the period 2010-14. The impact of working capital management has been analyzed using multiple regression models between WCM and profitability. The current study indicates a negative relationship between profitability and the cash conversion cycle, which was used as a measure of working capital management efficiency. Therefore it seems that operational profitability dictates how managers or owners will act in terms of managing the working capital of the firm. It has been observed that lower profitability is associated with an increase in the number days of accounts payables. The above could lead to the conclusion that less profitable firms wait longer to pay their bills taking advantage of credit period granted by their suppliers. The positive relationship between accounts receivables and firms' profitability suggests that more profitable firms will pursue an increase of their accounts receivables in an attempt to increase their profitability. Unlike wise the negative relationship between number of days in inventory and corporate profitability suggests that in the case of a sudden drop in sales accompanied with a mismanagement of inventory will lead to tying up excess capital at the expense of profitable operations. Due to the significant statistical results, having rejected null hypothesis ( $\mathrm{H} 01, \mathrm{H} 02, \mathrm{H} 03, \mathrm{H} 04)$ and accepted the alternative hypothesis (H11, H12, H13, H14). Therefore managers can create profits for their companies by handling correctly the cash conversion cycle and keeping each different component (accounts receivables, accounts payables, inventory) to an optimum level. Besides, the study prompts the researchers to investigate the relationship between working capital management and the firm's profitability with a broader set of companies operating in Bangladesh.

Elaborations: $\mathrm{DSE}=$ Dhaka Stock Exchange and $\mathrm{CSE}=$ Chittagong Stock Exchange

\section{References}

[1] Afza, T, \& Nazir, M. S. (2007). Working capital management policies of firms: Empirical evidence from Pakistan. Journal of Economics and Finance, 20 (1), pp. 33-46.

[2] Chiou, J. R., Cheng L., and Wu, H. W. (2006). The determinants of working capital management. Journal of American Academy of Business 10 (1), Cambridge, pp. 149155.

[3] Deloof, M. (2003). Does working capital management affect profitability of Belgian firms? Journal of Business Finance \& Accounting, 30 (3), 573-587.

[4] Einarsson, T., and Marquis, M. H. (2001). Bank intermediation over the business Cycle. Journal of Money, Credit and Banking 33 (4), pp. 876-899.

[5] Eljelly, A. (2004). Liquidity-Profitability tradeoff: An empirical investigation in an emerging market. International Journal of Commerce \& Management, 14 (2), pp. 48-61.

[6] Gill A, Biger N and Mathur N (2010). The Relationship between Working Capital Management and Profitability: Evidence from the United States. Business and Economics Journal, Volume 2010; pp. 1-9.

[7] Jason Kasozi (2017). The effect of working capital management on profitability: a case of listed manufacturing firms in South Africa. Investment Management and Financial Innovations (open-access), $14 \quad(2-2), \quad 336-346 . \quad$ doi: 10.21511/imfi.14 (2-2). 2017.05.

[8] Jose, M. L., Lancaster, C. and Stevens, J. L. (1996). "Corporate return and CCC", Journal of Economics and Finance, Volume 20, pp. 33-46.

[9] kumar A, O. N \& Ramanan T. R (2013) Working Capital Management and profitability: A Sensitivity Analysis. International Journal of Research and Development: A Management review. Volume 2, pp. $52-58$.

[10] Lawal, A. A. a*, Abiola, B. I. b, Oyewole, O. M. c, (2015): Effect of Working Capital Management on the Profitability of Selected Manufacturing Companies in Nigeria, International Journal of Sciences: Basic and Applied Research (IJSBAR) Volume 19, No 2, pp 370-386.

[11] Lazaridis, I. \& Tryfonidis (2006). Relationship between working capital management and profitability of listed companies in Athens Stock Exchange. Journal of Financial management and analysis 19 (1); pp. 26-35.

[12] Lyroudi, K., \& Lazaridis, J. (2000). The cash conversion cycle and liquidity analysis of the food industry in Greece. April 2012, Volume 2, No. 4; pp. 189-203.

[13] Merville L. J., and Tavis, L. A. (1973). Optimal working capital management policies: A Chance-Constrained Programming Approach. Journal of Financial and Quantitative Analysis 8 (1), pp. 47-59.

[14] Mr. Shivakumar, and Dr. N Babitha Thimmaiah. (2016). “WORKING CAPITAL MANAGEMENT - IT'S IMPACT ON LIQUIDITY AND PROFITABILITY - A STUDY OF COAL INDIA LTD.” International Journal of Research Granthaalayah, 4 (12), 178-187. https://doi.org/10.5281/zenodo.223836. 
[15] Nazir, M. S., \& Afza, T. (2009). Working capital requirements and the determining factors in Pakistan. ICFAI Journal of Applied Finance, 15 (4), pp. 28-38.

[16] Niresh, J., Aloy, (2012). Trade-Off between Liquidity \& Profitability: A Study of Selected Manufacturing Firms on Srilanka. Journal of Arts, Science \& Commerce, University of Jaffna, Sri Lanka, Volume.-III, Issue-4 (2), October 2012; pp. $34-40$.

[17] Nzioki P. M, Kimeli S. K, Abudho M. R and Nthiwa J. M (2013) Management of working capital and its effect on profitability of manufacturing companies listed on Nairobi securities exchange (NSE), Kenya. IJBFMR 1; pp. 35-42.

[18] Padachi, K. (2006). Trends in working capital management and its impact on firms' performance: An analysis of Mauritian small manufacturing firms. International Review of Business Research Papers, 2 (2), pp. 45-58.

[19] Quayyum, S. T. (2011) Effects of Working Capital Management and Liquidity: Evidence from the Cement Industry of Bangladesh. Journal of Business and Technology (Dhaka) Volume-VI, Number-01, pp. 37-47.

[20] Qurashi, M., \& Zahoor, M. (2017). Working capital determinants for the UK pharmaceutical companies listed on the FTSE 350 Index. International Journal for Academic Research in Accounting, Finance and Management Sciences, (1).

[21] Raheman, A., \& Nasr, M. (2007). Working capital management and profitability-case of Pakistani firms. International Review of Business Research Papers, 3 (1), pp. 279-300.

[22] Sathyamoorthi, C. R. and L. B. Wally-Dima, (2008). "WCM: The Case of Listed Retail Domestic Companies in Botswana", Journal of Management Research, Vol. 7, Issue 5, pp. 7-24.

[23] Smith, M. Beaumont, E. Begemann, (1997). Measuring Association between Working Capital and return on Investment. South African Journal of Business Management. 28 (1); pp. 235-250.

[24] Sunday. E. O, Abiola I. and Lawrencia. O. O. (2012). Working Capital Management, Firms' Performance and Market Valuation in Nigeria. World Academy of Science, Engineering and Technology 6 (1), 2012; pp. 124-128.

[25] Zariyawati, M. A., M. N. Annuar, H. Taufiq and A. S. Abdul Rahim, (2009). WCM and Corporate Performance: Case of Malaysia”, Journal of Modern Accounting and Auditing, Vol. 5, Issue 11, pp. 47-54. 